\title{
WHAT WOULD LAURA INGALLS WILDER DO
}

The Union carpenters saw

the hawk catch the snake,

journeymen and fur trappers,

yelling "Fuck" and "Holy Fuck"

and "I fuckin' told you"

how rough it is in the country.

Tuesday's gone with the wind, Laura,

and we are standing on the side

of County Line Road,

completely windswept, completely in love

with the nail gun and the insulation.

Is it roadless? Is there a privy? Is it brick?

People want to live here in our town.

Proud Navy Mom,

Proud Mother of a United States Marine,

an elite mother of earth and paint and clean,

and our eyes are on the Aerostar,

the neighbor's yard,

the wolf that howls at the moon.

I seek not to sully you.

I know you will tell me where to live.

We are builders, you and me.

We live where we live,

don't we? 